\title{
Distribution AND HABITAT USE OF SMALL CETACEANS off Abrolhos Bank, eastern Brazil
}

\author{
Marcos Rossi-Santos ${ }^{1,2^{*}}$, Leonardo L. Wedekin ${ }^{1,2}$ and Renata S. Sousa-Lima ${ }^{13,4}$
}

\begin{abstract}
Aвstract: An eight year summary of opportunistic sightings of small cetaceans in Abrolhos Bank, eastern Brazil, is provided with reference to species distribution, habitat use and group size. Data were gathered from 1997 to 2004 during research cruises (more than 500 days of sampling effort) aiming to study the biology of humpback whales, and were analyzed using a geographic information system (GIS). Dolphin species were identified on 151 sightings: estuarine dolphin, Sotalia guianensis - 49\%; roughtoothed dolphin, Steno bredanensis - 16\%; and bottlenose dolphin, Tursiops truncatus - $9 \%$. These small cetaceans did not use the area similarly. Distance from coast, distance from nearest river entrance, distance from nearest coral reef, and depth significantly differed among the three species $(p<0.05)$. Estuarine dolphin distribution was more coastal and concentrated near Caravelas and Doce Rivers. Rough-toothed dolphin distribution was concentrated near the coral reefs in the northern region of the Abrolhos Bank, whereas bottlenose dolphins were widely distributed across the Bank, along various depth ranges. Although the three species coexisted in the northern region of the Abrolhos Bank, our data suggest each showed specific habitat use patterns.

Resumo: Um período de 8 anos de observações oportunistas de pequenos cetáceos no Banco de Abrolhos, costa leste do Brasil, foi analisado com referência à distribuição de cada espécie, uso de habitat e tamanho de grupo. Os dados foram coletados entre 1997 e 2004 durante cruzeiros de pesquisa sobre a biologia da baleia jubarte, totalizando mais de 500 dias de esforço amostral, e foram analisadas utilizando um sistema de informações geográficas (SIG). Três espécies de golfinhos foram identificadas em 151 avistagens: boto-cinza, Sotalia guianensis - 49\%; golfinho-de-dentes-rugosos, Steno bredanensis - 16\%; e golfinho-nariz-de-garrafa, Tursiops truncatus $-9 \%$. As três espécies utilizaram a área de formas diferentes. Todas as variáveis ambientais mensuradas (distância da costa, distância da foz de rio mais próxima, distância do recife de coral mais próximo e profundidade) apresentaram diferenças significativas entre as três espécies de golfinhos ( $p<0.05)$. A distribuição do boto-cinza foi a mais costeira e concentrada em duas áreas distintas, próximas ao Rio Doce e ao Rio Caravelas. O golfinho-de-dentes-rugosos apresentou distribuição concentrada próxima aos recifes de coral da região norte do Banco dos Abrolhos, enquanto o golfinho-nariz-de-garrafa foi a espécie mais amplamente distribuída ao longo do banco, explorando áreas de profundidades mais variadas. Apesar das três espécies coexistirem na região norte do Banco dos Abrolhos, nossos dados sugerem padrões de uso de habitat distintos entre as diferentes espécies de golfinhos.
\end{abstract}

KEYwORDs: rough-toothed dolphin, Steno bredanensis, bottlenose dolphin, Tursiops truncatus, estuarine dolphin ${ }^{5}$, marine tucuxi, Sotalia guianensis, spatial use, group size, Abrolhos Bank, Brazil.

\section{Introduction}

The cetacean community of Abrolhos Bank, eastern Brazil, includes large baleen whale species: humpback whale (Megaptera novaeangliae), and southern right whale (Eubalaena australis) (Martins et al., 2001; Morete et al., 2003a,b; Wedekin et al., 2004); and small odontocetes: estuarine dolphin (Sotalia guianensis), rough-toothed dolphin (Steno bredanensis), and the bottlenose dolphin (Tursiops truncatus) (Borobia et al., 1991; Lodi and Hetzel, 1998; Rossi-Santos et al., 2003; Wedekin et al., 2004).

The Abrolhos Bank is the main breeding ground for humpback whales in the Western South Atlantic (Siciliano, 1997). The importance of its calm and warm waters for large baleen whales (Siciliano, 1997; Martins et al., 2001) and its high diversity of corals and other marine organisms (Leão, 1994) has motivated the creation of a National Marine Park in the region. Nevertheless, the occurrence and distribution of small cetacean species in the bank and along the entire Brazilian coast are poorly documented.

Many factors can influence the structure of cetacean communities. Cetacean distribution has been related to several environmental factors such as depth, slope, sea surface temperature, abundance of prey and others (e.g., Selzer and Payne, 1988; Baumgartner, 1997; Jaquet and Gendron, 2002). The habitat requirements of each species, allied with other aspects of their biology (e.g., diet), may determine how different species partition their habitat. Understanding the differences on spatial and habitat use among the species of a community of marine predators may help plan strategies of conservation of their habitats, such as marine protected areas zoning, fisheries regulation and others.

This study offers a summary of opportunistic sightings of small cetaceans in Abrolhos Bank during an eight year period (1997-2004) aiming to provide information about: (1) distribution, (2) physical habitat use, and (3) group size of the species examined.

\footnotetext{
${ }^{1}$ Instituto Baleia Jubarte - IBJ / Humpback Whale Institute - Brazil. Rua Barão do Rio Branco, 26, Caravelas, BA 45900-000, Brazil.

${ }^{2}$ Zoology Graduate School. Universidade Federal do Paraná.

* Corresponding author, e-mail: marcos.rossi@baleiajubarte.com.br.

${ }^{3}$ Department of Natural Resources, Fernow Hall, Cornell University, Ithaca, NY 14853, USA.

${ }^{4}$ Bioacoustics Research Program, Cornell Laboratory of Ornithology - 159 Sapsucker Woods, Ithaca, NY 14850, USA.

${ }^{5}$ The genus Sotalia was recently separated in two species: the estuarine dolphin (Sotalia guianensis) and the tucuxi dolphin (Sotalia fluviatilis) based on cranial characteristics (Monteiro Filho et al., 2002) and genetic divergence (Cunha et al., 2005; Caballero et al., in press). The name estuarine dolphin has been recognized and proposed for marine Sotalia (Reeves et al., 2003).
} 


\section{Material and Methods}

Abrolhos Bank $\left(16^{\circ} 40^{\prime}-19^{\circ} 30^{\prime} \mathrm{S}\right.$ and $\left.38^{\circ} 00^{\prime}-39^{\circ} 30^{\prime} \mathrm{W}\right)$ is an enlargement of the Brazilian continental shelf located off the southern Bahia State, eastern Brazil (Figure 1). The continental shelf may be as wide as $240 \mathrm{~km}$ (east of Caravelas), and beyond the shelf depth increases abruptly to $\sim 2000 \mathrm{~m}$. The Abrolhos Bank can be divided into northern and southern regions, which have distinct physiographic characteristics.

The northern region, where the Abrolhos Archipelago is located, is shallow (rarely exceeding $30 \mathrm{~m}$ ) and is characterized by the most diverse coral reefs in the southern Atlantic Ocean (Leão, 1994). There are two coral reef arches parallel to the coast, the inner arch (including the Paredes reef) and the outer arch (including the Abrolhos reef), which is adjacent to the Abrolhos Archipelago. The coastal waters near Caravelas are influenced by a large estuarine-mangrove complex with approximately $66 \mathrm{~km}^{2}$ (Herz, 1991). The ocean bottom is heterogeneous, composed of a mosaic of sand, mud, and calcareous algae (Leão, 1994).

In contrast, the southern region is relatively deeper, the bottom is more homogeneous, and it lacks islands or coral reef formations. The coast is mainly composed of sandy beaches and small rivers, except in the southern bound of the Abrolhos Bank, near the Doce River mouth.

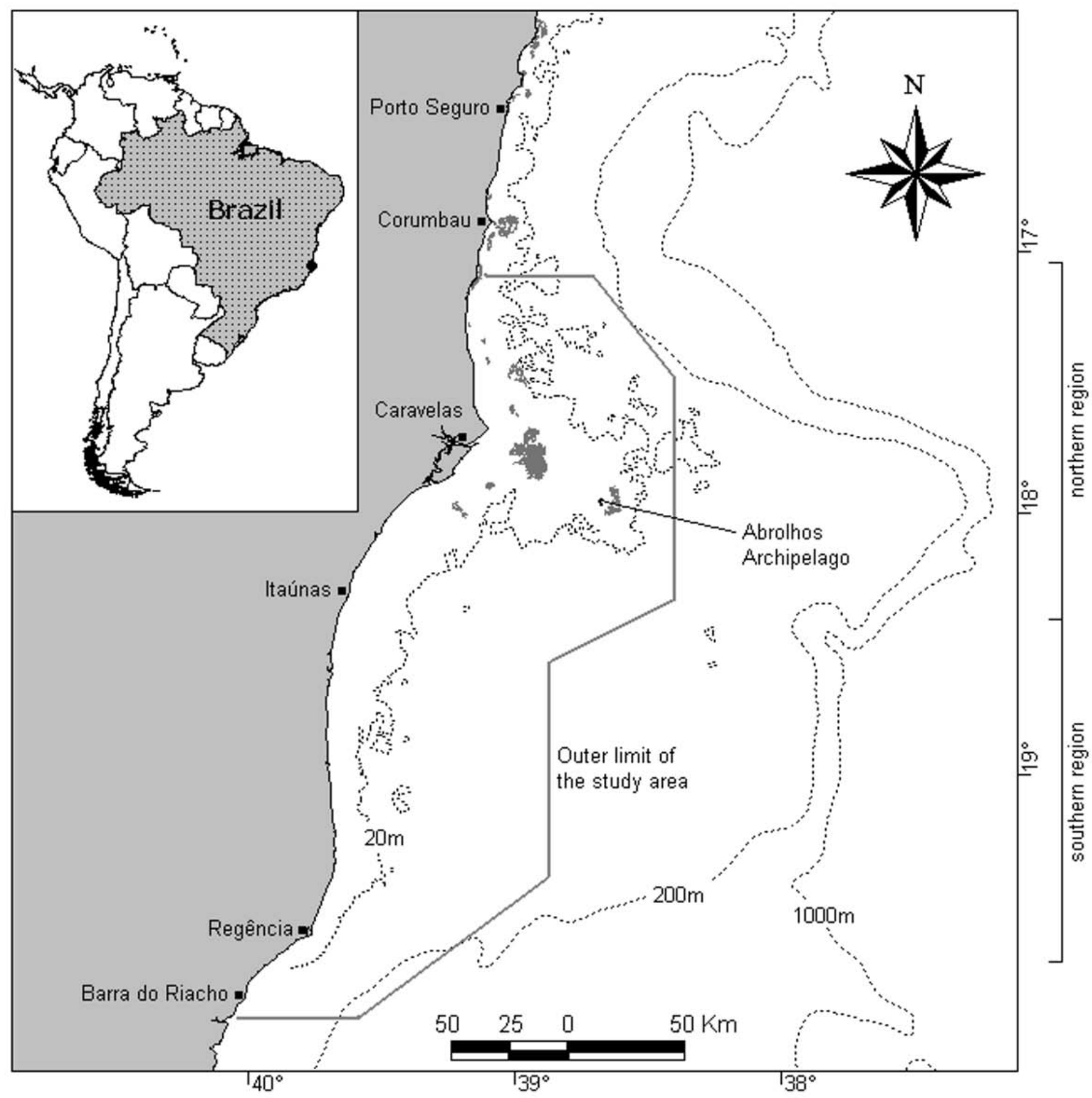

Figure 1. Study area of Abrolhos Bank, eastern coast of Brazil. Dark gray patches depict major coral reef formations. 
Opportunistic sightings occurred from July to November during weekly research cruises, which were conducted to study humpback whales off Abrolhos Bank (see Martins et al., 2001 for a detailed description). The surveys departed from Caravelas and lasted 3 to 7 days. Surveys were haphazard, and concentrated in the northern region of Abrolhos Bank and the Abrolhos Archipelago surroundings, but also included several cruises to the port of Barra do Riacho. The slope of the continental shelf, waters beyond $40 \mathrm{~m}$ deep and $80 \mathrm{~km}$ offshore were rarely surveyed. Diesel-powered, wooden boats (14 to $18 \mathrm{~m}$ ), or sail boats ( 8 to $18 \mathrm{~m})$ with outboard or center engines were primarily used for surveys. Species, group size, behavior, water depth (Echo-sounder) and geographical position (GPS) were collected for each sighting.

The routes to the southern part of Abrolhos Bank were farther from the coast and this possibly have resulted in less sightings of the estuarine dolphin between Caravelas and Regência. However, it is important to note that the habitats found in this stretch of coast are not usually occupied by large populations of Sotalia, and are not known to support these populations as observed near the Caravelas estuary and in front of the Doce River.

The geographical positions of the small cetacean groups observed were plotted on a digitized nautical chart of the area using ArcView GIS 3.2 (ESRI, Redlands, CA). The $95 \%$ fixed kernel method was used here as nonparametric probability density estimation for exploratory purposes (see Worton, 1989), corresponding to an area where there is a high probability of occurrence of the species based on the data gathered. This procedure was performed through the extension of ArcView called "The Animal Movement Analyst Extension - AMAE" (Hooge and Eichenlaub, 1997). The smoothing parameter of the fixed kernel was calculated through the "least square cross-validation" procedure (Worton, 1989), also using the AMAE extension.

Environmental variables including depth, distance from coast, distance from nearest river mouth, and distance from nearest coral reef formation were calculated for each sighting. Water depth was the only parameter collected during the cruises, while the other parameters were obtained through estimates from the digitized nautical chart of the study area after each sighting was plotted. Pearson correlation results indicated that environmental variables were not correlated $(p<0.05)$; therefore, all environmental variables were used for analyses. KruskalWallis (KW) analysis of variance was used to examine each variable among species (Zar, 1999). Data for non-identified species were not included in the analyses. All tests were performed using Statistica 5.0 (StatSoft, Inc., Tulsa, USA).

\section{Results}

Within an eight year period (1997 - 2004), and more than 500 days of sampling effort evenly distributed among the eight year period and the five months of the "whale season" (from July to November) (table 1), 212 groups of small cetacean were sighted in the Abrolhos Bank. During 151 sightings, 101 (49\%) estuarine dolphin groups; 32 (16\%) rough-toothed dolphin groups, and $18(9 \%)$ bottlenose dolphin groups were reliably identified.

Table 1. Years, number of sampling days and nautical miles navigated during the period comprising this study of small dolphins in Abrolhos Bank, Brazil.

\begin{tabular}{ccc}
\hline \hline YEAR & N OF SAMPLING DAYS * & NAUTICAL MILES \\
\hline \hline 1997 & 76 & 3280 \\
1998 & 62 & 2100 \\
1999 & 58 & 1800 \\
2000 & 72 & 1874 \\
2001 & 64 & 2040 \\
2002 & 66 & 1770 \\
2003 & 61 & 2072 \\
2004 & 47 & 1304 \\
Total & 506 & 16240 \\
\hline \hline
\end{tabular}

* Only minimum field efforts are shown. Efforts conducted without the IBJ's systematic surveys are not included.

Although the area was not surveyed randomly, small cetaceans did not appear to use the Abrolhos Bank area similarly (Figure 2). These three species used the waters around the Abrolhos Archipelago and around the outer and inner coral reef arches. Insofar, the bottlenose dolphin was the only species observed using the deep waters of the southern region of Abrolhos Bank, whereas rough-toothed dolphins were only observed in the northern region of the bank, mainly near the Abrolhos Archipelago and coral reefs. Estuarine dolphin sightings were concentrated in the northern region of the Abrolhos Bank and the vicinities of Doce River, near Regência, in the southern limit of the the bank. The estuarine dolphin was the most coastal, and its distribution was not continuous (showing two large distinct areas of concentration); rough-toothed dolphin had a more aggregated distribution (evidenced by the Kernel method, despite more sightings than bottlenose dolphins); and the bottlenose dolphin had the most widespread distribution along the Abrolhos Bank.

Environmental variables differed significantly among the three small cetacean species (depth: $\mathrm{KW}=62.9, \mathrm{DF}$ $=2, \mathrm{p}<0.05$; distance from coast: $\mathrm{KW}=62.9, \mathrm{DF}=2, \mathrm{p}<$ 0.05; distance from nearest river: $\mathrm{KW}=44.9, \mathrm{DF}=2, \mathrm{p}<$ 0.05 ; distance from nearest coral reef formation: $\mathrm{KW}=$ $14.5, \mathrm{DF}=2, \mathrm{p}<0.05)$ suggesting specific patterns of habitat use (Figure 3).

The estuarine dolphin was the only species using waters within $10 \mathrm{Km}$ from the coast (Figure 3a), but was also sighted at distances as much as $70 \mathrm{~km}$ from the coast in the Abrolhos Bank, and frequently observed near the Abrolhos Archipelago. Maximum 
distances of sightings from the coast were certainly influenced by our sampling design and may be underestimated for all species. Estuarine dolphin sightings also were closest to large river mouths (Figure $3 b$ ), and it was the only species observed to use estuarine habitats such as the estuary of the Caravelas River.

Estuarine dolphins occurred in shallow waters more often than the other two species (Figure 3c). The bottlenose dolphin was the most generalist species in relation to depth (using a broader depth range), whereas rough-toothed dolphins used the narrower depth range among the three species. Rough-toothed dolphin sightings were also closer to coral reef formations than the other two species (Figure 3d). If we consider only the northern population of Sotalia, the difference in the proximity of coral reefs between Steno and Sotalia is unlikely to occur.

Mean group size was similar among species. Roughtoothed dolphin mean group size was 4.6 individuals $(\mathrm{SD}=4.4$; range $=1-18)$, while slightly larger groups were observed for bottlenose dolphins ( mean $=5.4 ; \mathrm{SD}$ $=4.4$; range 1-20) and estuarine dolphins (mean $=6.6$; $\mathrm{SD}=11.5$; range $=1-100$ ). During one occasion, a large group of estuarine dolphins of approximately 100 individuals was observed near the Doce River.

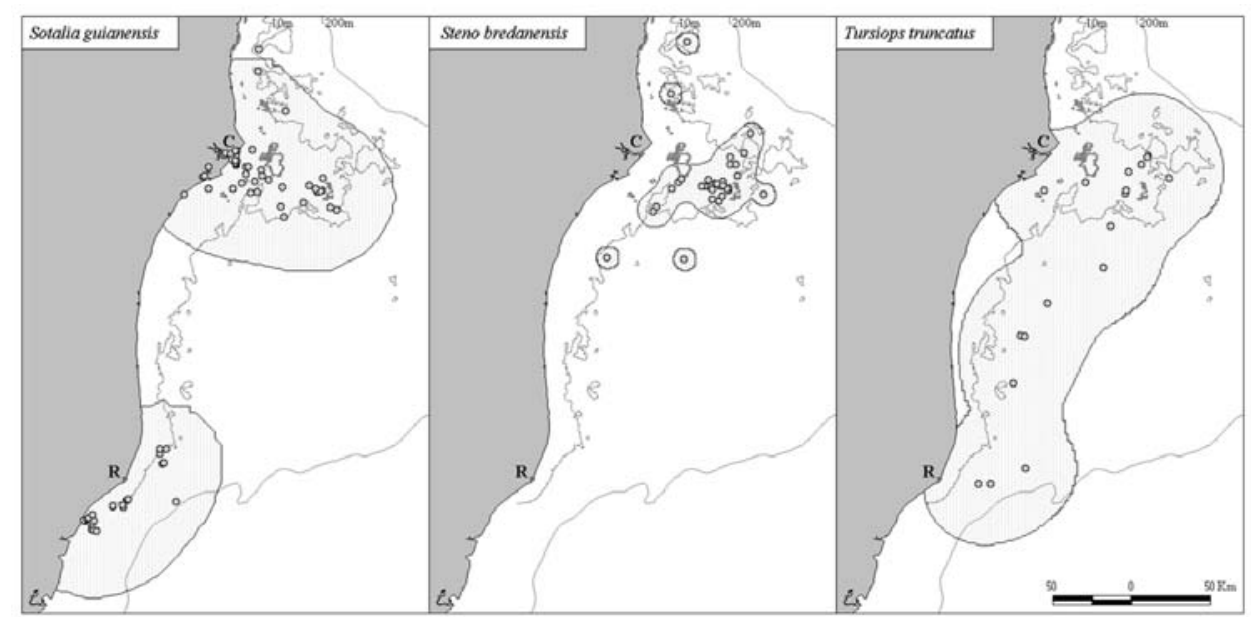

Figure 2. Sightings of each species in Abrolhos Bank from 1997 to 2004, and 95\% fixed kernel utilization distribution (shaded area). The towns of Regência and Caravelas are marked with the letters R and C, respectively.
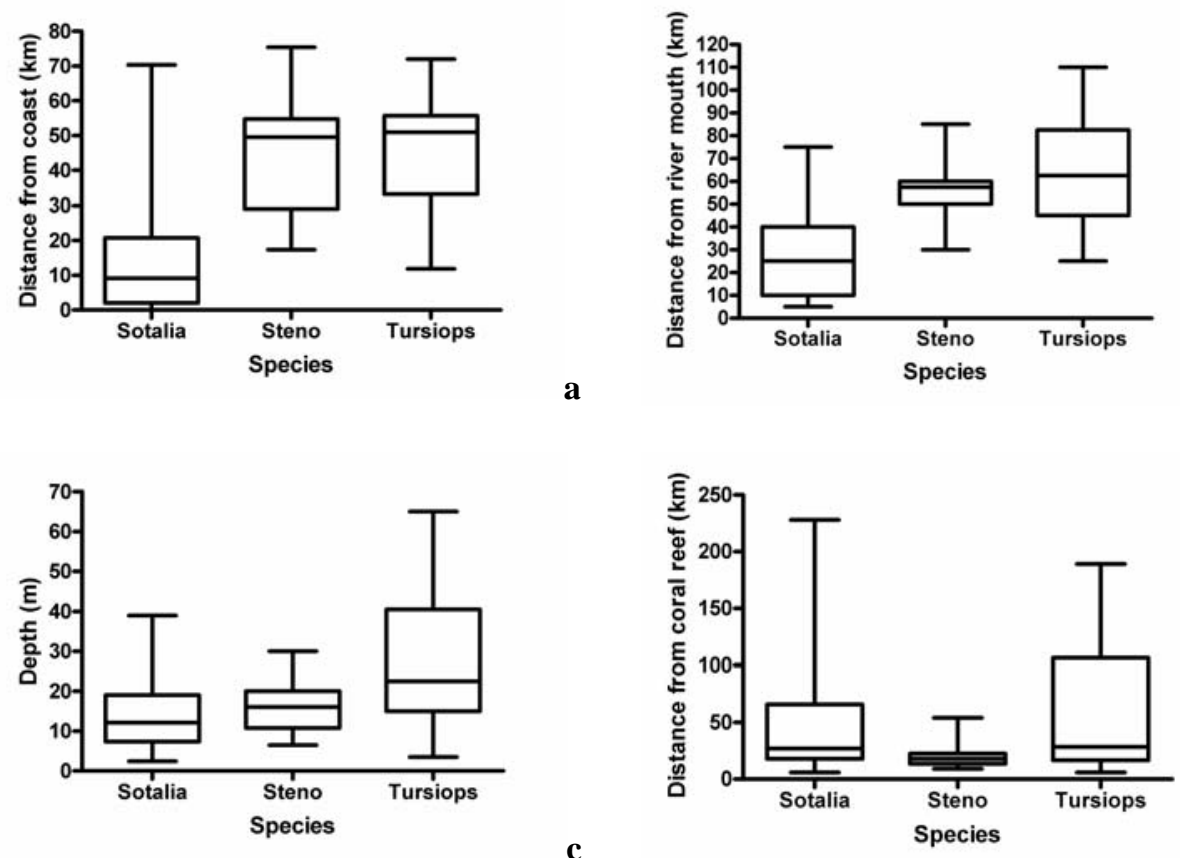

c

d

Figure 3. Distance from coast (a), distance from nearest river mouth (b), depth (c) and distance from coral reef (d) of sightings of the three species of small cetaceans off Abrolhos Bank, eastern Brazil. Box-plots show median, quartiles and extreme values. Differences among species for all parameters were significant (Kruskal-Wallis, $\mathrm{p}<0.05$ ). 


\section{Discussion}

The community of small cetacean in the coastal waters of Abrolhos Bank could be characterized by a low species richness. The Brazil Current is the predominant tropical warm water mass moving through Abrolhos Bank from north to south, limiting biological production in the area (Ekau, 1999).

Although the methods used for our study were not appropriate to infer on the relative abundance of small cetaceans, the most common species observed in the area was the estuarine dolphin. Accounts of rough-toothed and bottlenose dolphins may have been underestimated as a result of surveys being concentrated in areas where estuarine dolphins primarily occurred.

Sightings of franciscanas, Pontoporia blainvillei (Siciliano et al., 2002; Moreno et al., 2003) and records of killer whales (Orcinus orca), pilot whales (Globicephala sp.), pygmy/ dwarf sperm whales (Kogia sp.), Risso's dolphins (Grampus griseus) and P. blainvillei washed ashore indicate that other cetacean species may use the Abrolhos Bank. However, these species were not observed during this study.

Distinct habitat use patterns by the three small cetacean species were suggested by our data. The extensive overlap of distribution of the three species in the northern Abrolhos Bank region may result from the heterogeneity of habitats observed in the area, especially bottom physiography.

The offshore distribution of estuarine dolphins only ranged as far as the Abrolhos Archipelago region, possibly because of the extension of shallow and warm waters in this area (Borobia et al., 1991). The species was not observed throughout the entire Abrolhos Bank, between the towns of Regência and Nova Viçosa, supporting the view that it is concentrated in coastal and productive riverine systems (Wedekin et al., 2004 ${ }^{6}$ ), such as the Caravelas estuarinemangrove system, and the Doce River mouth and its vicinities. Areas devoided of estuaries, protected bays, large river discharges, and other habitat characteristics that induce coastal and localized productivity may serve as dispersal barriers, and/or may not support large populations of estuarine dolphins.

The distribution of rough-toothed dolphins around the Abrolhos Archipelago and coral reef surroundings was likely due to the association of its potential prey items to coral reef communities, and the foraging strategies described for this species in Brazilian coastal waters (Lodi and Hetzel, 1999). One of the prey items of rough-toothed dolphins captured while interacting with humpback whales in the Abrolhos Bank, the sharksucker (Echeneis naucrates) (Wedekin et al., 2004), is generally found in shallow reef sites such as those found in the northern region of the
Abrolhos Bank (Randall, 1983). Rough-toothed dolphin foraging strategies in coastal waters may include pushing fish school against the coast (Lodi and Hetzel, 1999). Our sightings of rough-toothed dolphins confirm what was previously reported by Lodi and Hetzel (1998), that this species inhabits the Brazilian shelf, besides its cosmopolitan occurrence in the shelf slope. Thus, the presented data showed that the difference in habitat use between Sotalia and Steno is distance from coast and river mouths.

The bottlenose dolphin was the most generalist species in terms of habitat use, which corroborates the information reported in the literature. This species is a known generalist predator (Connor et al., 2000), which may account for its broader occurrence in the area.

Both rough-toothed and bottlenose dolphins were not observed using coastal waters less than $12 \mathrm{~km}$ from shore. This pattern was similar to that observed for humpback whales, which appeared to avoid the chronic turbid coastal waters of the Abrolhos Bank, with high concentration of suspended material (Freitas, 2000). Knoppers et al. (1999) identified clear differences of mineral composition of suspended matter among inshore, coastal, and open reef waters of the Abrolhos Bank. A similar gradient was also verified in permanent and tidal currents and plankton composition (Knoppers et al., 1999). All these different environmental variables may have indirectly influenced small cetacean distribution as a result of their foraging ecology.

The information about the small cetacean community of Abrolhos Bank may be greatly enriched with a homogeneous sampling effort across the whole Abrolhos Bank (including the continental slope) and across all seasons, reducing the possible bias inherent of opportunistic data.

\section{Acknowledgements}

We wish to thank Marcia Engel, Milton Marcondes, Maria E. Morete, and Cristiane A. Martins for critical suggestions on an early draft. Vítor Q. Piacentini and Fábio Daura Jorge made valuable suggestions to the final manuscript, and all crewmembers of the boats "Tomara", especially captain Ubirajara "Bira", Wilson and César; "Piloto"; and "Coronado" for their great support at sea. Petrobras and Aracruz Celulose provided essential financial support to the Instituto Baleia Jubarte. Support to RSSL was given by the Brazilian Government (CAPES PhD scholarship), The Canon National Parks Science Scholars Program, Parque Nacional Marinho dos Abrolhos (ParNaM Abrolhos/ IBAMA), Conservação Internacional do Brasil, Marinha do Brasil, and Abrolhos Turismo. Eduardo Secchi and two anonymous referees provided useful comments to improve this manuscript.

\footnotetext{
${ }^{6}$ Wedekin, L. L., Daura-Jorge, F. G. and Simões-Lopes, P. C. (2004) Distribuição das populações de Sotalia guianensis na costa sul do Brasil: síntese do conhecimento atual e diretrizes para estudos futuros. Page 59 in Resúmenes de la XI Reunión de Trabajo de Especialistas en Mamíferos Acuáticos de América del Sur, Quito.
} 


\section{References}

BAumgartner, M.F. (1997) The distribution of risso's dolphin (Grampus griseus) with respect to the physiography of the northern Gulf of Mexico. Marine Mammal Science 13: 614-638.

Borobia, M., Siciliano, S., Lodi, L. And Hoek, W. (1991) Distribution of the South American dolphin Sotalia fluviatilis. Canadian Journal of Zoology 69: 1025-1039.

Caballero, S., Trujillo, F., Vianna, J.A., Barrios-Garrido, H., Montiel, M.G., Beltrán-Pedreros, S., Marmontel, M., Santos, M.C.O., Rossi-Santos, M.R., Santos, F.R. AND BAKER, C.S. (in press). Taxonomic status of the genus Sotalia: species level ranking for "tucuxi" (Sotalia fluviatilis) and "costero" dolphins (Sotalia guianensis). Marine Mammal Science.

Connor, R.C., Wells, R.S., Mann, J. and Read, A. (2000) The Bottlenose Dolphin: Social Relationships in a Fission-Fusion Society. Pages 91-126 in MAnN, J., CONNOR, R.C., TYACK, P. AND WhITEHEAD (Eds) Cetacean Societies: Field Studies of Dolphins and Whales. The University of Chicago Press, Chicago and London.

Cunha, H.A., Silva, V.M.F., LaIlson-Brito Jr, J., SAntos, M.C.O., Flores, P.A.C., Martin, A.R., Azevedo, A.F., Fragoso, A.B.L., Zanelatto, R.C. and Sole-Cava, Am M. (2005) Riverine and marine ecotypes of Sotalia dolphins are different species. Marine Biology 148: 449-457.

EKAU, W. (1999) Topographical and hydrographical impacts on zooplancton community structure in the Abrolhos Bank region, East Brazil. Archive of Fishery and Marine Research 47: 307-320.

FREITAS, C.M.A. (2000) Spatial and seasonal distribution of humpback whales, Megaptera novaeangliae, wintering in Abrolhos, Brazil. M.Sc. thesis, University of Aberdeen, Scotland. 59 pp.

Herz, R. (1991) Manguezais do Brasil. Editora da Universidade de São Paulo, São Paulo.

Hooge, P.N. and Eichenlaub, B. (1997) Animal Movement Extension to ArcView (version 1.1). Alaska Biological Science Centre, United States Geological Survey, Anchorage.

JAQUET, N. AND GENDRON, D. (2002) Distribution and relative abundance of sperm whales in relation to key environmental features, squid landings and the distribution of other cetacean species in the Gulf of California, Mexico. Marine Biology 141: 591-601.

Knoppers, B., Meyerhöfer, M., Marone, E., Dutz, J., Lopes, R., LeIPE, T. AND CAMARGO, R. (1999) Compartments of the pelagic system and material exchange at the Abrolhos Bank coral reefs, Brasil. Archive of Fishery and Marine Research 47: 285-306.

LEÃo, Z.M.A.N. (1994) Os recifes de coral do sul da Bahia. Pages 151-159 in Hetzel, B. and Castro, C.B. (Eds) Corais do Sul da Bahia. Editora Nova Fronteira, Rio de Janeiro.

Lodi, L. AND Hetzel, B. (1998) O golfinho-de-dentes-rugosos (Steno bredanensis) no Brasil. Bioikos 12: 29-45.

Lodi, L. ANd Hetzel, B. (1999) Rough-toothed dolphin, Steno bredanensis, feeding behaviors in Ilha Grande Bay, Brazil. Biociências 7: 29-42.

Martins, C.C.A., Morete, M.E., Engel, M.H., Freitas, A.C., SecChI, E.R. AND KINAS, P.G. (2001) Aspects of habitat use patterns of humpback whales in the Abrolhos Bank, Brazil, breeding ground. Memoirs of the Queensland Museum 47: 563-570.

Monteiro Filho, E.L.A., Monteiro, L.R. And Reis, S.F. (2002)
Skull shape and size divergence in dolphins of the genus Sotalia: A tridimensional morphometric analysis. Journal of Mammalogy 83: 125-134.

Moreno, I.B., Martins, C.C.A., Andriolo, A. And Engel, M.H. (2003) Sightings for fransciscana dolphins (Pontoporia blainvillei) off Espírito Santo, Brazil. Latin American Journal of Aquatic Mammals 2: 131-132.

Morete, M.E., Freitas, A., Engel, M.H., Pace III, R.M. and ClaPhAM, P.J. (2003a) A novel behavior observed in humpback whales on wintering grounds at Abrolhos Bank (Brazil). Marine Mammal Science 19: 694-707.

Morete, M.E., Pace III, R.M., Martins, C.C.A., Freitas, A. and Engel, M.H. (2003b) Indexing seasonal abundance of humpback whales around Abrolhos Archipelago, Bahia, Brazil. Latin American Journal of Aquatic Mammals 2: 21-28.

Randal, J.E. (1983) Caribbean Reef Fishes. 2nd edition. TFH Publications, Neptune City.

Reeves, R.R., Smith, B.D., Crespo, E.A. and Notarbartolo dI SciarA, G. (Eds) (2003). Dolphins, Whales and Porpoises: 2002 2010 Conservation Action Plan for the World's Cetaceans. IUCN/SSC Cetacean Specialist Group. Switzerland: IUCN.

Rossi-Santos, M.R., Wedekin, L.L. and Engel, M.H. (2003) Behavioral ecology of the Sotalia guianensis dolphins in the extreme southern Bahia region. Revista de Etologia (suplemento especial) 5: 200-201.

Selzer L.A. and Payne, P.M. (1988) The distribution of white-sided (Lagenorhynchus acutus) and common dolphins (Delphinus delphis) vs. environmental features of the continental shelf of the northeastern United States. Marine Mammal Science 4: 141-153.

Siciliano, S. (1997) Características da população de baleias jubarte (Megaptera novaeangliae) na costa brasileira, com especial referência aos Bancos de Abrolhos. M.Sc. thesis, Universidade Federal Rural do Rio de Janeiro, Rio de Janeiro, Brasil. 113 pp.

Siciliano, S., Di Beneditto, A.P. And Ramos, R. (2002) A toninha, Pontoporia blainvillei (Gervais and d'Orbigny, 1844) (Mammalia, Cetacea, Pontoporiidae), nos Estados do Rio de Janeiro e Espírito Santo, costa sudeste do Brasil: caracterização dos hábitats e possíveis fatores de isolamento das populações. Boletim do Museu Nacional, Nova Série, Zoologia 146: 1-15.

Wedekin, L.L., Freitas, A., Engel, M.H. ANd SAzIMA, I. (2004) Rough-toothed dolphins (Steno bredanensis) catch diskfishes while interacting with humpback whales (Megaptera novaeangliae) off Abrolhos Bank breeding ground, Southwest Atlantic. Aquatic Mammals 30: 327-329.

WorTON, B.J. (1989) Kernel methods for estimating the utilization distribution in home-range studies. Ecology 70: 164-168.

ZAR, J. H. (1999) Biostatistical Analysis. 4th edition. Prentice Hall, Upper Saddle River. 663 pp.

Received 5 June 2005. Accepted 18 April 2006. 